\title{
IMPLEMENTASI BAHAN AJAR KALULUS LANJUT BERBASIS INKURI
}

\author{
Nurul Farida ${ }^{1)}$, Rina Agustina ${ }^{2)}$ \\ ${ }^{1,2}$ Universitas Muhammadiyah Metro \\ Email: nurulfaridamath@gmail.com ${ }^{1)}$; aasyiqun1212@gmail.com ${ }^{2)}$
}

\begin{abstract}
In advanced calculus learning is needed teaching materials that can help students understand the concept. One of the teaching materials that can be used is by applying teaching materials that contains the problem of understanding the concept of advanced calculus. This instructional material can be arranged with inquiry-based. The research design used is Pre-Experimental Design with One-Group Pretest-Posttest Design type. From result of research, obtained $t$ count equal to 11,8 and t tabel equal to 1,645 mean value of concept comprehension after given instructional materials advanced calculus based on inquiry is significantly better than before using advanced calculus based instructional materials inquiry. Based on the results of data analysis concluded that the instructional materials advanced inquiry-based advanced calculus developed effectively can improve the ability of students' concept of understanding on advanced calculus learning.
\end{abstract}

Keywords: advanced calculus, implementation of teaching materials, inquiry

\section{PENDAHULUAN}

Dalam pembelajaran Kalkulus Lanjut dibutuhkan pemahaman konsep (conceptual understanding) mahasiswa untuk dapat menyelesaikan masalah tentang turunan tingkat tinggi dan integral lipat. Namun pada kenyataanya, pemahaman konsep peserta didik masih kurang memuaskan. Berdasarkan hasil prasurvei didapatkan bahwa pemahaman konsep mahasiswa matematika pada mata kuliah kalkulus lanjut masih rendah. Hal ini terlihat dari perolehan nilai kalkulus lanjut dari 40 mahasiswa pada tahun ajaran 2015/2016 dengan rata-rata nilai kuis yaitu 29,21 dengan nilai tertinggi 60 dan nilai terendah 5 .

Menurut Murizal, Yarman, dan Yerizon (2012), pemahaman konsep merupakan salah satu kompetensi yang dibutuhkan dalam mengemukakan kembali ilmu yang diperoleh kepada orang lain baik secara lisan ataupun tulisan sehingga orang lain tersebut mengerti dengan apa yang dikemukakan. Kemampuan pemahaman konsep matematis merupakan salah satu indikator pencapaian siswa memahami konsepkonsep matematika yang telah dipelajari selama proses pembelajaran. Berdasarkan hal definisi pemahaman konsep, dapat terlihat bahwa dalam pembelajaran kalkulus lanjut diperlukan sarana yang dapat membantu mahasiswa memahami konsep. Salah satu sarana yang dapat digunakan yaitu dengan menerapkan bahan ajar yang memuat masalah tentang pemahaman konsep kalkulus lanjut. Bahan ajar ini dapat disusun dengan menggunakan inkuri. Menurut Siagian dan Nurfitriyanti (2012), "Inquiry merupakan salah satu metode mengajar yang erat kaitannya dengan menempatkan mahasiswa sebagai 
subjek belajar yang aktif. Metode inkuiri merupakan metode pembelajaran yang berupaya menanamkan dasar-dasar berfikir ilmiah pada diri mahasiswa, sehingga dalam proses pembelajaran ini mahasiswa lebih banyak belajar sendiri, mengembangkan kreativitas dalam memecahkan masalah. Mahasiswa benar-benar ditempatkan sebagai subjek yang belajar. Inkuiri mengandung proses mental yang lebih tinggi tingkatannya, seperti merumuskan masalah, merencanakan eksperimen, melakukan eksperimen, mengumpulkan dan menganalisa data, menarik kesimpulan."

Pernyataan ini juga didukung oleh Kulshrestha, et al (2014), "Inquiry based teaching learning encourages students with a chance to form knowledge, and skills. Inquiry based teaching learning has to be appreciated because it is necessary as a tool for developing systemic, systematic and critical thinking skills, problem solving capabilities and the creativity of students. The three main steps are followed while developing an Inquiry based lesson plan:

a. Content analysis- Select a class or grade and analyze the content of the prescribed textbook of that class.

b. Selection of content- Select the appropriate content from the prescribed textbook with due consideration to the applicability of the inquiry based teaching learning approach.

c. Development of inquiry based lesson plan. There are many lesson plan formats are available on web and the lesson plan format of inquiry based learning (mentioned below) can also be used as a reference lesson plan format for developing learning material and it would be proved appropriate for regular classroom."

Pembelajaran berbasis inkuri mendorong siswa dengan memberi kesempatan untuk membentuk pengetahuan, dan keterampilan. Pembelajaran berbasis inkuri harus dihargai karena itu diperlukan alat untuk mengembangkan kemampuan berpikir sistemik, sistematis dan kritis, pemecahan masalah kemampuan dan kreativitas siswa. Tiga langkah ketika mengembangkan pembelajaran berbasis inkuri:

a. Isi analisis atau menganalisis isi buku teks yang ditentukan dari kelas itu.

b. Pemilihan konten yang sesuai dari buku teks yang ditentukan dengan memperhatikan penerapan pendekatan pembelajaran berbasis inquiry.

c. Mengembangkan perencanaan pembelajaran berbasis inkuri. Pengembangan pelajaran berdasarkan rencana pelajaran yang tersedia di web dan format rencana pembelajaran berbasis inkuri juga dapat digunakan sebagai referensi format rencana pelajaran untuk mengembangkan materi pembelajaran dan itu akan menjadi sesuai untuk kelas reguler.

Proses penyusunan bahan ajar berbasis inkuiri melalui tahapan yaitu meneliti, merancang dan menguji pada implementasi pembelajaran. Proses penyusunan ini merujuk pada Sugiyono (2015;30), "penelitian dan pengembangan diartikan sebagai cara untuk meneliti, merancang, memproduksi dan menguji validitas produk yang telah dihasilkan. Memvalidasi produk berarti peneliti hanya menguji efektivitas atau validitas produk tersebut."

Pada bahan ajar ini memuat materi kalkulus lanjut mengenai turunan 
tingkat tinggi dan integral lipat. Materi ini juga didukung oleh pernyataan Purcell, et al (2007), materi integral lipat membahas mengenai perubahan variable dalam integral lipat dengan menggunakan metode Jacobian. Selain materi integral lipat, akan dibahas juga materi persamaan diferensial termasuk tentang bidang kemiringan (slope) dan metode Euler. Menurut Ayres, Mendelson, dan Elliot (2006), materi kalkulus III (Kalkulus Lanjut) adalah Integral lipat-dua dan integral berulang.

\section{METODE PENELITIAN}

Penelitian dilaksanakan di Universitas Muhammadiyah Metro pada Program Studi Pendidikan Matematika. Subjek penelitian ini adalah mahasiswa pendidikan matematika semester 3 yang mengikuti perkulihan Kalkulus Lanjut. Untuk melihat efektifitas penggunaan bahan ajar, maka akan dilakukan uji coba sebelum dan setelah diberi perlakuan menggunakan bahan ajar berbasis inkuiri. Variabel yang diamati dalam penelitian ini terdiri dari variabel bebas yaitu penggunaan bahan ajar berbasis inkuri dan variabel terikat yaitu pemahaman konsep mahasiswa pada pembelajaran Kalkulus Lanjut.

Pada implementasi produk, dilakukan uji coba produk. Desain penelitian yang digunakan adalah PreEksperimental Design dengan tipe OneGroup Pretest-Posttest Design. Desain penelitian sangat diperlukan dalam perencanaan dan pelaksanaan penelitian. Pada desain One-Group Pretest-Posttest Design, terdapat pretest sebelum diberi perlakuan dan posttest setelah diberi perlakuan. Dengan demikian hasil perlakuan dapat diketahui lebih akurat, karena dapat membandingkan dengan keadaan sebelum diberi perlakuan.

$$
\text { Sebelum melakukan uji }
$$

statistik,nilai tes akhir akan diuji
Selain itu, akan dipelajari juga materi integral lipat tiga dan persamaan diferensial orde pertama dan kedua.

Berdasarkan masalah tersebut, maka dalam pembelajaran kalkulus lanjut akan menggunakan bahan ajar berbasis inkuri yang memuat masalahmasalah pemahaman konsep.Dengan menggunakan bahan ajar inkuri maka akan dapat terlihat efektivitas bahan ajar terhadap pemahaman konsep mahasiswa dalam pembelajaran kalkulus lanjut.

normalitas menggunakan uji Liliefors dan uji hipotesis statistik yang digunakan dalam penelitian ini adalah uji beda rerata untuk data berpasangan (Budiyono, 2016: 160). Hipotesis yang digunakan sebagai berikut.

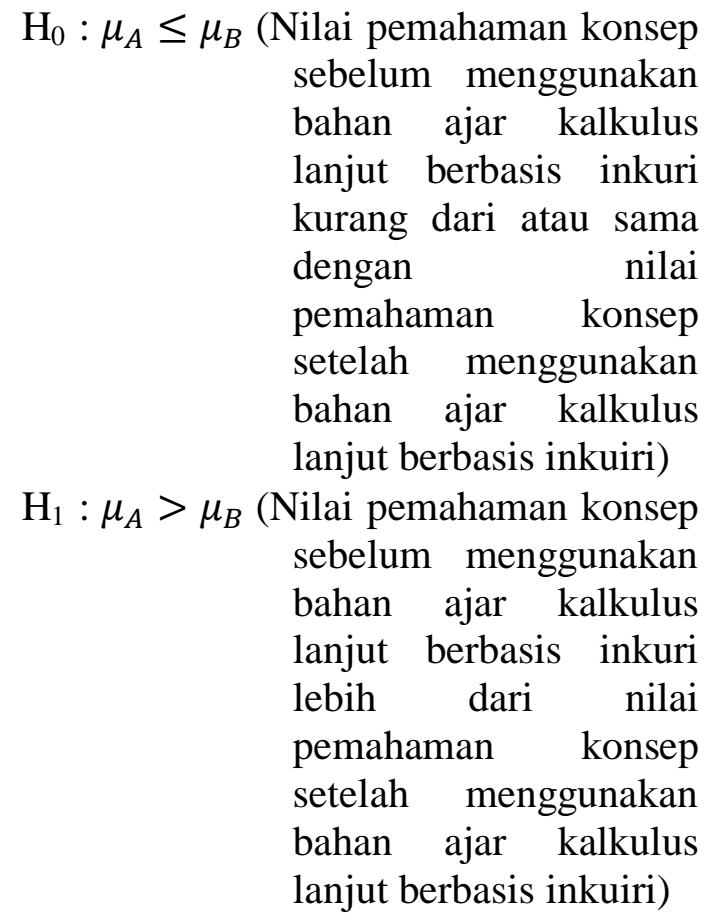

\section{HASIL PENELITIAN DAN PEMBAHASAN}

Sebelum dilakukan tahap implementasi, terlebih dahulu dilakukan uji lapangan awal yaitu uji perorangan. Bahan ajar prototype 1 yang telah divalidasi selanjutnya diberikan kepada tiga orang mahasiswa. Pada tahap ini 
mahasiswa diberikan angket untuk memberikan masukan mengenai kekurangan bahan ajar pada prototype
1. Hasil uji coba lapangan disajikan pada Tabel 1.

Tabel 1. Hasil Analisis Uji Coba Lapangan Awal

\begin{tabular}{|c|c|c|}
\hline Siswa & Skor & Kategori \\
\hline 1 & 31 & Baik \\
\hline 2 & 30 & Baik \\
\hline 3 & 32 & Baik \\
\hline Rata-rata & 31 & Baik \\
\hline
\end{tabular}

Tabel 1. merupakan hasil uji coba lapangan. Rata-rata nilai yang diperoleh adalah 31 dari skor maksimum 40 sehingga dapat dikategorikan baik.

Dari hasil uji lapangan awal ini,dilakukan revisi pada bahan ajar. Selanjutnya, hasil revisi ini, dilakukan uji lapangan utama yaitu uji prototype 2 pada kelompok kecil. Pada uji ini, akan digunakan 3 kelompok kecil yang masing-masing terdiri dari tiga orang mahasiswa. Selanjutnya, pada masingmasing kelompok akan diberikan angket untuk melihat kekurangan dari prototype 2. Hasil uji coba lapangan disajikan pada Tabel 2.

Tabel 2. Hasil Analisis Uji Coba Lapangan Utama

\begin{tabular}{|c|c|c|}
\hline Siswa & Skor & Kategori \\
\hline Kelompok 1 & 35 & Sangat Baik \\
\hline Kelompok 2 & 35 & Sangat Baik \\
\hline Kelompok 3 & 33 & Sangat Baik \\
\hline Rata-rata & 34,3 & Sangat Baik \\
\hline
\end{tabular}

Tabel 2 merupakan hasil uji coba lapangan. Rata-rata nilai yang diperoleh adalah 34,3 dari skor maksimum 40 sehingga dapat dikategorikan sangat baik. Hasil uji coba lapangan ini didukung oleh Kulshrestha, et al (2014) yang menjelaskan pembelajaran berbasis inkuiri merupakan bagian dari pendekatan kontruktivisme. Dalam pembelajaran berbasis inkuiri, guru bertindak sebagai fasilitator yang menciptakan situasi belajar yang berbeda dan memfasilitasi siswa untuk menyelidiki dan mengambil pengalaman yang berbeda. Jadi, guru harus harus membuat perecanaan semua kegiatan pengajaran.

Setelah dilakukan revisi dari hasil uji coba lapangan, maka tahap selanjutnya adalah melakukan tahap implementasi bahan ajar kalkulus lanjut berbasis inkuiri.

Tahap implementasi pada penelitian ini adalah melakukan uji coba produk dengan menerapkan dan menggunakan bahan ajar kalkulus lanjut berbasis inkuiri pada mata kuliah kalkulus lanjut. Pembelajaran ini dilakukan pada pertemuan 1 sampai dengan pertemuan ke-4. Pada pertemuan 1, dilakukan terlebih dahulu pretes untuk mendapatkan data awal tentang pemahaman konsep mahasiswa. Selanjutnya, pada pertemuan ke-4 dilakukan tes postes untuk mendapatkan nilai akhir pemahaman konsep 
mahasiswa setelah menggunkan bahan ajar kalkulus lanjut berbasis inkuiri. Berikut data nilai hasil tes pemahaman konsep mahasiswa sebelum dan setelah menggunakan bahan ajar kalkulus lanjut berbasis inkuiri.

Tabel 3. Data Nilai Pemahaman Konsep Mahasiswa

\begin{tabular}{|l|c|c|c|c|}
\hline Kelompok & $\mathbf{N}$ & $\mathbf{X}_{\text {maks }}$ & $\mathbf{X}_{\min }$ & $\mathbf{s}$ \\
\hline Pretes & 46 & 98 & 15 & 10,49 \\
\hline Postes & 46 & 45 & 0 & 19,20 \\
\hline
\end{tabular}

Setelah didapatkan nilai pretes dan postes, tahap selanjutnya adalah melakukan uji normalitas terhadap data nilai pemahaman konsep baik pada nilai pretes maupun postes. Uji normalitas

Tabel 4. Uji Normalitas Data Nilai Pemahaman Konsep Mahasiswa

\begin{tabular}{|c|c|c|c|c|c|}
\hline Kelompok & $\mathbf{n}$ & $\mathbf{L}_{\mathbf{o b s}}$ & $\mathbf{L}_{\mathbf{0}, \mathbf{0 5} ; \mathbf{n}}$ & Keputusan & Kesimpulan \\
\hline Pretes & 46 & 0,1250 & 0,1306 & $\mathrm{H}_{0}$ diterima & Normal \\
\hline Postes & 46 & 0,1117 & 0,1306 & $\mathrm{H}_{0}$ diterima & Normal \\
\hline
\end{tabular}

Selanjutnya dilakukan uji hipotesis untuk mengetahui keefektifan bahan ajar yang digunakan. Uji hipotesis yang digunakan adalah uji beda rerata untuk data berpasangan atau untuk melihat signifikansi nilai pemahaman konsep sebelum dan setelah menggunakan bahan ajar kalkulus lanjut berbasis inkuiri. Berdasarkan uji hipotesis diperoleh hasil bahwa nilai $t_{\text {hitung }}$ sebesar 11,8 dan $t_{\text {tabel }}$ sebesar 1,645. Karena nilai $t_{\text {hitung }}>t_{\text {tabel }}$. Maka diperoleh keputusan uji tolak $\mathrm{H}_{0}$. Hal ini berarti nilai pemahaman konsep setelah diberikan bahan ajar kalkulus lanjut berbasis inkuiri signifikan lebih baik dibandingkan sebelum menggunakan bahan ajar kalkulus lanjut berbasis inkuiri. Jadi diperoleh kesimpulan bahwa bahan ajar kalkulus lanjut berbasis inkuiri yang dikembangkan terbukti efektif untuk meningkatkan kemampuan pemahaman konsep mahasiswa pada pembelajaran kalkulus lanjut.

Hasil penelitian ini juga didukung oleh Molina (2014) yang menjelaskan yang digunakan adalah uji liliefors. Data uji normalitas pada kelompok pretes dan postes dapat dilihat pada tabel 4 berikut. bahwa prestasi matematika siswa di seluruh Amerika Serikat dapat meningkat dengan melompati komponen umum dari instruksi matematika dan sebaliknya berfokus pada bahasa instruksional dan pemahaman yang mendalam tentang konsep-konsep matematika, pendidik dapat membantu siswa mengembangkan keterampilan matematika yang diperlukan untuk kemajuan dan inovasi dalam bidang STEM.

\section{KESIMPULAN DAN SARAN}

Berdasarkan hasil dan pembahasan diperoleh kesimpulan sebagai berikut.

1. Pada tahap uji coba lapangan diperoleh nilai rata-rata 31 dengan kategori baik.

2. Pada tahap uji lapangan utama diperoleh nilai rata-rata 34,3 dengan kategori sangat baik.

3. Pada tahap implementasi diperoleh nilai $t_{\text {hitung }}$ sebesar 11,8 dan $t_{\text {tabel }}$ sebesar 1,645 berarti nilai pemahaman konsep setelah 
diberikan bahan ajar kalkulus lanjut berbasis inkuiri signifikan lebih baik dibandingkan sebelum menggunakan bahan ajar kalkulus lanjut berbasis inkuiri

4. Bahan ajar kalkulus lanjut berbasis inkuiri yang dikembangkan efektif dapat meningkatkan kemampuan pemahaman konsep mahasiswa pada pembelajaran kalkulus lanjut.

Berdasarkan hasil penelitian diberikan saran, yaitu:

1. Dalam pembelajaran kalkulus lanjut dapat menggunakan bahan ajar berbasis inkuri untuk meningkatkan kemampuan pemahaman konsep mahasiswa.

2. Bagi mahasiswa, untuk dapat menggunakan dan menyelesaikan masalah-masalah pemahaman konsep dalam bahan ajar berbasis inkuiri.

\section{DAFTAR PUSTAKA}

Ayres, F., Mendelson, dan Elliot. 2006. Kalkulus Edisi Keempat. Jakarta: Erlangga.

Budiyono. 2016. Statistika Untuk Penelitian. Surakarta: UNS Press.

Kulshrestha, A.K., et. al. 2014. How To Develop Inquiry Based Learning Material. International Journal of Advanced Research. Vol. 2. No. 5. Hal 972 - 975.

Molina. 2014. Teaching Mathematics Conseptually. SEDL Insights Advancing Research Improving Education. Vol. 1. No. 4.

Murizal, A., Yarman, dan Yerizon. 2012. "Pemahaman Konsep Matematis dan Model Pembelajaran Quantum
Teaching”. Jurnal Pendidikan Matematika UNP. Vol. 1 No. 1 Hal $19-23$.

Purcell, et al. 2007. Kalkulus Edisi Kesembilan Jilid 2. Jakarta: Erlangga.

Siagian, R.E.F. dan Nurfitriyanti, M. 2012. Metode Pembelajaran Inquiry dan Pengaruhnya Terhadap Hasil Belajar Matematika Ditinjau dari Kreativitas Belajar. Jurnal Formatif. Vol 2. No. 1. Hal 35 44.

Sugiyono. 2015. Metode Penelitian dan Pengembangan. Bandung: Alfabeta. 